\title{
Influence of dietary supplementation with sunflower oil and quebracho tannins on growth performance and meat fatty acid profile of Awassi lambs
}

\author{
H.E.M. Kamel ${ }^{\mathrm{a}}$, S.N. Al-Dobaib ${ }^{\mathrm{b}}$, A.Z.M. Salem ${ }^{\mathrm{c}, *}$, S. López ${ }^{\mathrm{d}}$, P.A. Alaba ${ }^{\mathrm{e}}$ \\ ${ }^{a}$ Department of Animal and Fish Production, Faculty of Agriculture, University of Alexandria (El-Shatby), Alexandria, P.O. 21545, Egypt \\ ${ }^{\mathrm{b}}$ Department of Animal Production and Breeding, Faculty of Agriculture and Veterinary Medicine, Qassim University, Buriedah, 51452, P.O. Box \\ 6622, Saudi Arabia \\ ${ }^{\mathrm{c}}$ Facultad de Medicina Veterinaria y Zootecnia, Universidad Autónoma del Estado de México, Toluca, Mexico \\ ' Instituto de Ganadería de Montaña (IGM) CSIC-Universidad de León, Departamento de Producción Animal, Universidad de León, E-24071 León, \\ Spain \\ e Department of Chemical Engineering, University of Malaya, 50603 Kuala Lumpur, Malaysia
}

\section{A R T I C L E I N F O}

\section{Keywords:}

Sunflower oil

Quebracho tannins

Fatty acids profile

Lambs meat

\begin{abstract}
A B S T R A C T
The influence of dietary supplementation with quebracho tannins (QT) or/and sunflower oil (SF) on growth performance and fatty acid profile in meat of Awassi lambs was studied. Seventy-two lambs were assigned randomly to nine diets ( 8 per group) in the experiment following a $3^{2}$ factorial design with all possible combinations of two factors, SF and QT each at three levels i.e. 0 (control), 20 or $40 \mathrm{~g} / \mathrm{kg}$ diet DM. A significant SF $\times$ QT interaction was observed on the conjugated linoleic acid content of intramuscular fat $(P=0.007)$, but not on average daily weight gain $(P=0.11)$. Addition of QT at $40 \mathrm{~g} / \mathrm{kg}$ DM significantly increased average daily gain comparing to control diet. The inclusion of QT in the diet increased the content of the conjugated linoleic acid in the lamb meat above that achieved with SF supplementation only. Addition of the combination of QT and SF to the diet enhanced the content of conjugated linoleic acid (C18:2 c9t11) of the lamb meat. This could be due to the reduction in the bio-hydrogenation of unsaturated fatty acids in the diet. The results suggest that inclusion the combination of QT and SF in lamb diets improved the healthy fatty acids content in the meat without an adverse effect on animal performance.
\end{abstract}

\section{Introduction}

Meat and milk products obtained from ruminants are natural sources of conjugated linoleic acid (CLA), predominantly cis-9, trans11 CLA (rumenic acid). Conjugated linoleic acid is characterized by the presence of double bonds in conjugated positions in 18-C fatty acids synthesized as intermediates during incomplete biohydrogenation of cis-9, cis-12, cis-15 C18:3 (linolenic acid) and cis-9, cis-12 C18:2 (linoleic acid) in rumen before conversion into the final product of ruminal biohydrogenation, C18:0 (stearic acid) (Bessa et al., 2005). Along with CLA, incomplete ruminal biohydrogenation of linoleic acid also results in the synthesis of trans-11 C18:1 (vaccenic acid). When greater proportion of vaccenic acid is synthesized during ruminal biohydrogenation, most of the rumenic acid is synthesized endogenously by desaturation of vaccenic acid via $\Delta^{9}$-desaturase (Piperova et al., 2002).

Various strategies have been proposed to increase the CLA content in meat and milk products, which includes supplementing

\footnotetext{
* Corresponding author.

E-mail address: asalem70@yahoo.com (A.Z.M. Salem).
} 
concentrates rich in linoleic acid or feeding pasture-based diets (Vargas-Bello-Pérez and Larraín, 2017). These strategies are based on increasing ruminal synthesis of vaccenic acid, thereby increasing uptake of the respective fatty acid in duodenum resulting in greater endogenous synthesis of rumenic acid in the mammary gland (Vasta et al., 2009b). Cruz-Hernandez et al. (2007) reported that the diet supplementation with sunflower oil (SF, i.e. 15, 30 and $45 \mathrm{~g} / \mathrm{kg} \mathrm{DM}$ ), in the presence of $5 \mathrm{~g} / \mathrm{kg}$ of fish oil, linearly increased total C18:1 t11 and total CLA. Al-Dobaib and Kamel (2012) reported a five-fold increase in CLA content of milk fat when camels were fed diets supplemented with $20 \mathrm{~g}$ SF/ kg feed, compared with control diet. Similarly, Díaz et al. (2005) showed that the fatty acid profile of diet affects the fatty acid profile of lamb meat to a greater extent than other factors like age, sex, or breed (Díaz et al., 2005).

At an appropriate level of tannins, the $\mathrm{N}$ release from the dietary protein degradation may be reduced in the rumen, thereby, increasing the absorption of amino acids in the small intestine. Consequently, tannins have been suggested to be suitable feed additives towards improving the digestive utilization of dietary protein (Hernandez et al., 2014; Salem et al., 2014). Nevertheless, tannins may also cause negative effects like reduction of ruminal degradation of organic matter (OM) or decreasing fiber and dry matter (DM) digestion when supplied at 30 rather than at 10 and $20 \mathrm{~g}$ tannins/kg DM (Al-Dobaib, 2009; Ammar et al., 2011; Salem et al., 2013). In general, condensed tannins can reduce the activity of ruminal microorganisms (Priolo et al., 2000; Cieslak et al., 2014). It has been shown that dietary tannins lowered ruminal biohydrogenation in vitro and increased muscle $\Delta^{9}$-desaturase protein expression (Vasta et al., 2009a,b) in sheep.

The objective of this work is to study the effects of dietary supplementation with quebracho tannins (QT) or/and sunflower oil (SF) on the growth performance and fatty acid profile in the meat of Awassi lambs. The potential synergistic effects of QT and SF are also examined.

\section{Materials and methods}

\subsection{Experimental location and diets}

This work was conducted at the Agricultural Research Station, Qassim University, Saudi Arabia. Diets were formulated and pelleted at the Arabian Agricultural Services Company (ARASCO)-Riyadh, Saudi Arabia. In a complete randomized design with a $3^{2}$ factorial arrangement of the treatments, three levels (0,20 and $40 \mathrm{~g} / \mathrm{kg}$ of diet DM) of either SF or QT were evaluated. The amount of tannin supplementation used was in accordance with the report of Carulla et al., 2005 who observed that less than $50 \mathrm{~g} / \mathrm{kg}$ DM can positively influence animal performance and feed digestion, whereas more than $50 \mathrm{~g}$ tannins/ $\mathrm{kg}$ DM may be reduce the animal growth and health. The SF was acquired from the local supermarket in Riyadh. A commercial tannin source (Unitan ATO, Saica, Argentina) from quebracho plant (Schinopsis spp.) was employed as a source of condensed tannins (contained 75\% (w/w) condensed tannins). The treatments comprised all possible combinations of the three levels $(0,20$ or $40 \mathrm{~g} / \mathrm{kg}$ DM of the diet) of QT or/and SF, including the control with neither QT nor SF. Diets were formulated to be isoenergetic and isonitrogenous (Table 1).

\subsection{Sample preparation}

The samples of the nine diets were ground to pass a 1-mm screen (standard model 4, Arthur H. Thomas Co., Philadelphia, PA) and kept for later analyses. Analytical DM content of the samples was obtained by drying in the oven at $135^{\circ} \mathrm{C}$ for $3 \mathrm{~h}$; organic matter (OM) was obtained by ashing, and Kjeldahl N content was determined using Foss-Kjeltec 8200 (Hoganas, Sweden; AOAC, 1995). The neutral detergent fibre (aNDFom) and acid detergent fibre (ADFom) concentrations were sequentially determined using Foss-Fibertec 2010 Analyzer (Foss, Sweden) according to the methodology described by Van Soest et al. (1991) using sodium sulfite and pretreatment with heat-stable amylase (Type XI-A from Bacillus subtilis; Sigma-Aldrich Corporation, St. Louis, MO).

\subsection{Growth trial and fatty acids profile of meat}

Seventy-two male Awassi (Noami, Saudi local name) lambs (90 days old) with a body weight of $21.5 \pm 0.09 \mathrm{~kg}$ (mean \pm SD) were divided into 9 groups ( 8 animals per treatment) and raised with their dams. Each dam and its offspring were housed in an individual pen. Animals in each group were fed one of the 9 experimental diets. After weaning at about $90 \mathrm{~d}$ of age, dams were removed and lambs remained in the same pens and fed the same assigned experimental diets for a further 70-d growth trial. The weight of lambs were recorded at the start of the growth trial and then at weekly (7-d) intervals. Feed and water were withdrawn $15 \mathrm{~h}$ before weighing. All animals were fed ad libitum and had free access to drinking water and minerals blocks. During the growth trial, feed given and refusals were recorded daily. Samples of each diet were taken once weekly to determine the DM content. The feed conversion ratio and average daily gains were calculated.

The lambs were slaughtered at the end of the 70-d growth trial and the carcasses were split lengthwise. The right longissimus dorsi (LD, between 10th and 13th ribs) was removed within $20 \mathrm{~min}$ after slaughtering and stored at $-80^{\circ} \mathrm{C}$ until analysis. Intramuscular fatty acids of LD muscle were extracted as described by Folch et al. (1957). Briefly, a 3-g sample of LD muscle was homogenized in chloroform-methanol $(2: 1 \mathrm{v} / \mathrm{v})$, kept at room temperature and sonicated for 5 min every $2 \mathrm{~h}$ for $6 \mathrm{~h}$. The residue was filtrated from the homogenized solution and dried at room temperature $\left(\sim 20^{\circ} \mathrm{C}\right)$. The fatty acids in the meat were transmethylated using sodium methoxide and then the fatty acids were converted to their corresponding methyl esters by adding $2 \mathrm{ml}$ of $0.5 \mathrm{M}$ sodium methoxide $\left(10 \mathrm{~min}\right.$ at $50{ }^{\circ} \mathrm{C}$ ) and $3 \mathrm{ml}$ of $5 \%$ methanolic $\mathrm{HCl}\left(\mathrm{v} / \mathrm{v} ; 10 \mathrm{~min}\right.$ at $80^{\circ} \mathrm{C}$ ) as suggested by Kramer et al. (1997). Fatty acid methyl esters in hexane were injected into a Shimadzu 2010A gas chromatograph equipped with a FID detector, and a fused silica capillary column of $0.2 \mu \mathrm{m}$ phase film, $100 \mathrm{~m} \times 0.25 \mathrm{~mm}$ i.d. (SP 2560; Supelco, Inc., Bellefonte, PA) for fatty acids separation. Samples containing 
Table 1

Ingredients, chemical and fatty acid compositions of experimental diets.

\begin{tabular}{|c|c|c|c|c|c|c|c|c|c|}
\hline \multirow{2}{*}{$\begin{array}{l}\text { Diet } \\
\text { Level }(\mathrm{g} / \mathrm{kg})\end{array}$} & \multirow{2}{*}{$\begin{array}{l}\text { Control } \\
0\end{array}$} & \multicolumn{2}{|c|}{ Quebracho tannins (QT) } & \multicolumn{2}{|c|}{ Sunflower oil (SF) } & \multicolumn{4}{|l|}{$\mathrm{QT}+\mathrm{SF}$} \\
\hline & & 20 & 40 & 20 & 40 & $20+20$ & $40+40$ & $20+40$ & $40+20$ \\
\hline \multicolumn{10}{|l|}{ Ingredients, $\mathrm{g} / \mathrm{kg}$ DM } \\
\hline Alfalfa hay & 144 & 149 & 153 & 149 & 153 & 153 & 161 & 157 & 157 \\
\hline Palm kernel meal & 150 & 150 & 150 & 150 & 150 & 150 & 150 & 150 & 150 \\
\hline Barley grain & 426 & 396 & 367 & 396 & 367 & 367 & 308 & 338 & 338 \\
\hline Wheat bran & 100 & 100 & 100 & 100 & 100 & 100 & 100 & 100 & 100 \\
\hline Canola meal & 70 & 70 & 70 & 70 & 70 & 70 & 70 & 70 & 70 \\
\hline Soybean meal & 32 & 37 & 42 & 37 & 42 & 42 & 53 & 47 & 47 \\
\hline Molasses & 50 & 50 & 50 & 50 & 50 & 50 & 50 & 50 & 50 \\
\hline Lime-stone & 10 & 10 & 10 & 10 & 10 & 10 & 10 & 10 & 10 \\
\hline Salt & 5 & 5 & 5 & 5 & 5 & 5 & 5 & 5 & 5 \\
\hline Vitamins + minerals ${ }^{\mathrm{a}}$ & 13 & 13 & 13 & 13 & 13 & 13 & 13 & 13 & 13 \\
\hline Sunflower oil (SF) ${ }^{\mathrm{b}}$ & - & - & - & 20 & 40 & 20 & 40 & 40 & 20 \\
\hline Quebracho tannins (QT) & - & 20 & 40 & - & - & 20 & 40 & 20 & 40 \\
\hline \multicolumn{10}{|l|}{ Chemical composition, $\mathrm{g} / \mathrm{kg}$} \\
\hline Dry matter & 921 & 918 & 922 & 901 & 881 & 912 & 887 & 891 & 898 \\
\hline Organic matter & 931 & 918 & 918 & 927 & 932 & 919 & 927 & 926 & 927 \\
\hline Crude protein & 139 & 144 & 15 & 145 & 138 & 142 & 142 & 143 & 141 \\
\hline Ether extract & 25 & 25 & 21 & 37 & 60 & 40 & 64 & 61 & 38 \\
\hline Neutral detergent fibre (aNDFom) & 351 & 348 & 336 & 340 & 352 & 336 & 360 & 357 & 334 \\
\hline Acid detergent fibre (ADFom) & 174 & 172 & 171 & 165 & 177 & 173 & 186 & 179 & 184 \\
\hline Acid detergent lignin(sa) & 34 & 33 & 34 & 34 & 39 & 40 & 40 & 34 & 45 \\
\hline $\mathrm{GE}^{\mathrm{c}}(\mathrm{MJ} / \mathrm{kg})$ & 18.2 & 18.2 & 18.1 & 18.4 & 18.9 & 18.5 & 19 & 18.9 & 18.5 \\
\hline \multicolumn{10}{|c|}{ Fatty acid compositions, $g / 100 \mathrm{~g}$ of total fatty acids methyl esters ${ }^{\mathrm{b}}$} \\
\hline $\mathrm{C} 14: 0$ & 0.42 & 0.4 & 0.44 & 0.23 & 0.17 & 0.24 & 0.2 & 0.19 & 0.26 \\
\hline $\mathrm{C} 16: 0$ & 21.8 & 22.3 & 20.9 & 14.6 & 12.6 & 13.9 & 13.3 & 12.9 & 14.9 \\
\hline C18:0 & 10.9 & 11.3 & 11.1 & 8.14 & 6.83 & 8.9 & 6.1 & 6.3 & 7.95 \\
\hline C18:1 (cis-9) & 15 & 16.1 & 14.9 & 24.3 & 22.9 & 24.7 & 23.4 & 23.1 & 23.9 \\
\hline C18:2 (cis-9, cis-12) & 51.9 & 52.5 & 53 & 52.8 & 57.5 & 54.1 & 58 & 56.8 & 53.1 \\
\hline
\end{tabular}

${ }^{\mathrm{a}}$ Contained (per kilogram): $90.2 \mathrm{~g}$ of Ca, $49.0 \mathrm{~g}$ of P, $48.9 \mathrm{~g}$ of Mg, $17.6 \mathrm{~g}$ of S, $140 \mathrm{~g}$ of Na, $14.3 \mathrm{~g}$ of K, $2.07 \mathrm{~g}$ of Fe, $1.9 \mathrm{~g}$ of Mn, $2.7 \mathrm{~g}$ of Zn, $447 \mathrm{mg}$ of Cu, $69 \mathrm{mg}$ of I, $7 \mathrm{mg}$ of Co, $20 \mathrm{mg}$ of Se, $452 \mathrm{IU}$ of vitamin A, $58 \mathrm{IU}$ of vitamin D, and $2692 \mathrm{IU}$ of vitamin E.

${ }^{\mathrm{b}}$ Containing (g/100 g total fatty acids methyl esters): C16:0 (5.5), C18:0 (4.6), cis-9 C18:1 (34.5) and cis-9, cis-12 C18:2 (52.1).

${ }^{\mathrm{c}} \mathrm{GE}=$ growth energy.

fatty acids methyl esters in hexane $(1 \mu \mathrm{l})$ were injected through the split injection port at the ratio of 50:1 with a linear He flow of $25 \mathrm{~cm} / \mathrm{s}$. The oven temperature was maintained at $60{ }^{\circ} \mathrm{C}$ for $5 \mathrm{~min}$, then increased to $170{ }^{\circ} \mathrm{C}$ at the rate of $3{ }^{\circ} \mathrm{C} / \mathrm{min}$. It was held for $10 \mathrm{~min}$ at $170^{\circ} \mathrm{C}$, and later increased to $230^{\circ} \mathrm{C}$ at $5{ }^{\circ} \mathrm{C} / \mathrm{min}$ and then held for $20 \mathrm{~min}$. The temperature of the detector and injector was $250{ }^{\circ} \mathrm{C}$ and total run time was $83.5 \mathrm{~min}$. Fatty acids of intramuscular fat were identified by comparing their retention times with those of a fatty acids methyl esters standard mixture (Cat.\# O5632, Sigma-Germany \& Cat.\# 47885-U, Supelco, Bellefonte, PA-USA). The individual concentration was determined by taking the area of the specific fatty acids as a percentage of total fatty acids and were expressed as $\mathrm{g} / 100 \mathrm{~g}$ of fatty acids methyl esters.

\subsection{Statistical analysis}

Performance and fatty acid profile data were analysed by using the mixed procedure of SAS (SAS Institute, 2001). The statistical model included the fixed influence of SF level in the diet (0, 20 or $40 \mathrm{~g} / \mathrm{kg}$ of DM), QT level $(0,20 \mathrm{or} 40 \mathrm{~g} / \mathrm{kg}$ of DM) and the interaction between SF level in the diet and QT. The animal was the random term. The initial body weight at day 0 of growth trial was used as a covariate term to test the effects on final weight. Linear and quadratic trends in the response to the level of inclusion of sunflower oil or of the addition of quebracho tannins were evaluated by using orthogonal polynomial contrasts. Least square means were separated by Duncan's multiple range tests.

\section{Results and discussion}

\subsection{Growth performance and meat fatty acids profile}

Neither SF nor the interaction of SF $\times$ QT had significant effects on total feed intake, total weight gain, average daily gain and feed conversion of fattening lambs (Table 2). Supplementation of QT at $20 \mathrm{~g} / \mathrm{kg}$ increased $(P<0.05)$ average daily gain compared to control, however, diets with $40 \mathrm{~g}$ QT/ $\mathrm{kg}$ had an intermediate value between control diet and $20 \mathrm{~g}$ QT/ $\mathrm{kg}$ diet (Table 2). The formation of hydrogen bonds between the carboxyl group of peptides and the polymer phenolic sub-units leads to tannin-protein complexes that could prevent the protein from being degraded in the rumen rather than abomasal digestion since their stabilities 
Table 2

Growth performance and chemical composition of longissimus dorsi (LD) muscle as influenced by different levels ( $\mathrm{g} / \mathrm{kg}$ DM of the diet) of quebracho tannin (QT) and/or sunflower oil (SF) supplementation of lamb diets (Number of animals used 8 per diet).

\begin{tabular}{|c|c|c|c|c|c|c|c|}
\hline \multirow[t]{2}{*}{ Diets } & \multirow[t]{2}{*}{$\begin{array}{l}\text { Initial body } \\
\text { weight }(\mathrm{kg})\end{array}$} & \multirow[t]{2}{*}{$\begin{array}{l}\text { Final body } \\
\text { weight }(\mathrm{kg})\end{array}$} & \multirow[t]{2}{*}{$\begin{array}{l}\text { Feed intake } \\
(\mathrm{kg} / \mathrm{d})\end{array}$} & \multirow[t]{2}{*}{$\begin{array}{l}\text { Average daily gain } \\
(\mathrm{g} / \mathrm{d})\end{array}$} & \multirow[t]{2}{*}{$\begin{array}{l}\text { Feed conversion (kg intake } \\
\mathrm{DM} / \mathrm{kg} \text { gain) }\end{array}$} & \multicolumn{2}{|c|}{$\begin{array}{l}\text { Chemical composition of LD }(\mathrm{g} / \mathrm{kg} \\
\text { of DM) }\end{array}$} \\
\hline & & & & & & $\mathrm{CP}$ & $\mathrm{EE}$ \\
\hline Control (0) & 21.5 & 34.1 & 1.03 & 181 & 5.78 & 825 & 178 \\
\hline \multicolumn{8}{|l|}{ QT } \\
\hline 20 & 21.7 & 37.0 & 1.26 & 219 & 5.81 & 744 & 181 \\
\hline 40 & 21.6 & 33.1 & 1.12 & 165 & 6.96 & 780 & 175 \\
\hline \multicolumn{8}{|l|}{ SF } \\
\hline 20 & 21.5 & 34.5 & 1.11 & 184 & 6.06 & 763 & 172 \\
\hline 40 & 21.9 & 34.6 & 1.14 & 181 & 6.45 & 753 & 179 \\
\hline \multicolumn{8}{|l|}{$\mathrm{QT}+\mathrm{SF}$} \\
\hline $20+20$ & 21.6 & 36.2 & 1.21 & 207 & 5.89 & 752 & 184 \\
\hline $40+40$ & 21.2 & 34.7 & 1.19 & 191 & 6.35 & 776 & 174 \\
\hline $20+40$ & 21.3 & 35.8 & 1.22 & 201 & 5.99 & 831 & 186 \\
\hline $40+20$ & 21.3 & 37.0 & 1.26 & 225 & 5.64 & 825 & 186 \\
\hline SEM & 0.09 & 0.65 & 0.06 & 12.9 & 0.34 & 5.6 & 8.7 \\
\hline \multicolumn{8}{|c|}{ Probability ( $P$-values) } \\
\hline SF effect & 0.961 & 0.687 & 0.523 & 0.281 & 0.378 & 0.961 & 0.815 \\
\hline Linear & 0.496 & 0.820 & 0.494 & 0.791 & 0.831 & 0.907 & 0.722 \\
\hline Quadratic & 0.698 & 0.340 & 0.575 & 0.334 & 0.244 & 0.859 & 0.650 \\
\hline QT effect & 0.954 & 0.345 & 0.019 & 0.031 & 0.382 & 0.705 & 0.842 \\
\hline Linear & 0.148 & 0.667 & 0.130 & 0.521 & 0.553 & 0.669 & 0.668 \\
\hline Quadratic & 0.847 & 0.071 & 0.106 & 0.102 & 0.323 & 0.675 & 0.082 \\
\hline $\mathrm{SF} \times \mathrm{QT}$ & 0.936 & 0.456 & 0.570 & 0.114 & 0.210 & 0.065 & 0.654 \\
\hline Reg. on IW $^{\mathrm{a}}$ & - & 0.956 & - & - & - & - & - \\
\hline \multicolumn{8}{|c|}{ Means for main effects } \\
\hline \multicolumn{8}{|l|}{$\mathrm{SF}$} \\
\hline 0 & 21.6 & 34.8 & 79.2 & 186 & 6.21 & 787 & 174 \\
\hline 20 & 21.5 & 35.9 & 83.1 & 204 & 5.88 & 782 & 179 \\
\hline 40 & 21.4 & 35.0 & 82.9 & 192 & 6.26 & 782 & 177 \\
\hline \multicolumn{8}{|l|}{ QT } \\
\hline 0 & 21.6 & 34.4 & $76.7^{\mathrm{y}}$ & $182^{\mathrm{y}}$ & 6.11 & 782 & 178 \\
\hline 20 & 21.4 & 36.3 & $85.9^{x}$ & $210^{x}$ & 5.90 & 773 & 188 \\
\hline 40 & 21.4 & 34.9 & $83.2^{x y}$ & $191^{x y}$ & 6.36 & 781 & 178 \\
\hline
\end{tabular}

${ }^{\mathrm{x}, \mathrm{y}}$ Means in the same column within main effect with no superscript letters after them or with a common superscript letter following them are not significantly different $(\mathrm{P}<0.05)$.

${ }^{\mathrm{a}}$ Regression on initial body weight.

depend on the level of $\mathrm{pH}$ (Barry and Manley, 1984). Butter et al. (1999) proposed that the high fecal-N output could be because of one or more of the following factors: (i) secretion of endogenous proteins; (ii) impaired intestinal function, (iii) reduction in ruminal and intestinal digestive enzymes activity because of tannins; and (iv) increased digesta protein bound to tannin. Komolong et al. (2001) reported that non ammonia-nitrogen reaching the small intestine can be reduced to some extent due to the increase in dietary condensed tannins. Therefore, the improvement of ADG due to QT is attributable to reduction in ruminal degradation of N, which led to an increase in the flow $\mathrm{N}$ to the post-ruminal tract for growth.

Significant differences between levels of supplements were detected for several meat fatty acids (Table 3). The main fatty acids of intramuscular fat in the present study were oleic (C18:1 c9), palmitic (C16:0) and stearic (C18:0) acids, which contributed to about $80 \%$ of total fatty acids in LD muscle. Effect of increasing level of SF supplementation was positive $(P=0.009)$ on the concentration of C16:0, however, QT supplementation had no significant effect. The proportion of C18:0 was lowered in a dose-response manner $(P=0.001)$ to the level of either SF or QT added to the diets. The percentage of C18:0 was lower $(P<0.003)$ because of either SF or QT additions (with a significant SF $\times$ QT interaction), and the control diet has the highest $(P<0.05)$ concentration compared with the other diets. Oleic acid concentration was higher $(P=0.001)$ in LD fat as a result of SF supplementation at 20 and $40 \mathrm{~g} / \mathrm{kg}$ of SF compared with the control diet, and no effect was detected for the QT level and the interaction effect of SF $\times$ QT. The CLA C18:2 $c 9 t 11$ content tended to decrease $(P=0.084)$ due to SF supplementation. However, C18:2 $c 9 t 11$ content was higher $(P<0.007)$ because of either QT level or SF $\times$ QT effects. Total CLA (i.e. sum of C18:2 c9t11 and C18:2 t10c12) content varied in response to SF supplementation, which was higher $(P<0.05)$ in diet with $40 \mathrm{~g} / \mathrm{kg}$ of SF compared to $20 \mathrm{~g} / \mathrm{kg}$ SF diet, and no difference was detected between control and SF added diets. The total CLA increases $(P<0.05)$ as the QT level in the diet increases. Total CLA for the $40 \mathrm{~g} / \mathrm{kg}$ QT was higher $(P<0.05)$ compared to control diet and no differences were reported between $20 \mathrm{~g} / \mathrm{kg}$ QT and either control or QT at $40 \mathrm{~g} / \mathrm{kg}$ of the diet. Moreover, the SF $\times$ QT interaction $(P<0.05)$ was found for total CLA content (Table 3).

The ratio of UFA/SFA of intramuscular fat in LD muscle was higher $(P<0.004)$ due to addition of either SF or QT to the diet; however, there was no significant $\mathrm{SF} \times \mathrm{QT}$ interaction. The sum of mono-unsaturated fatty acids (MUFA) was higher $(P=0.03)$ with $\mathrm{SF}$ at $40 \mathrm{~g} / \mathrm{kg}$ compared with control diet. There were no SF $\times$ QT interactions. The MCFA (sum of medium chain fatty acids, 


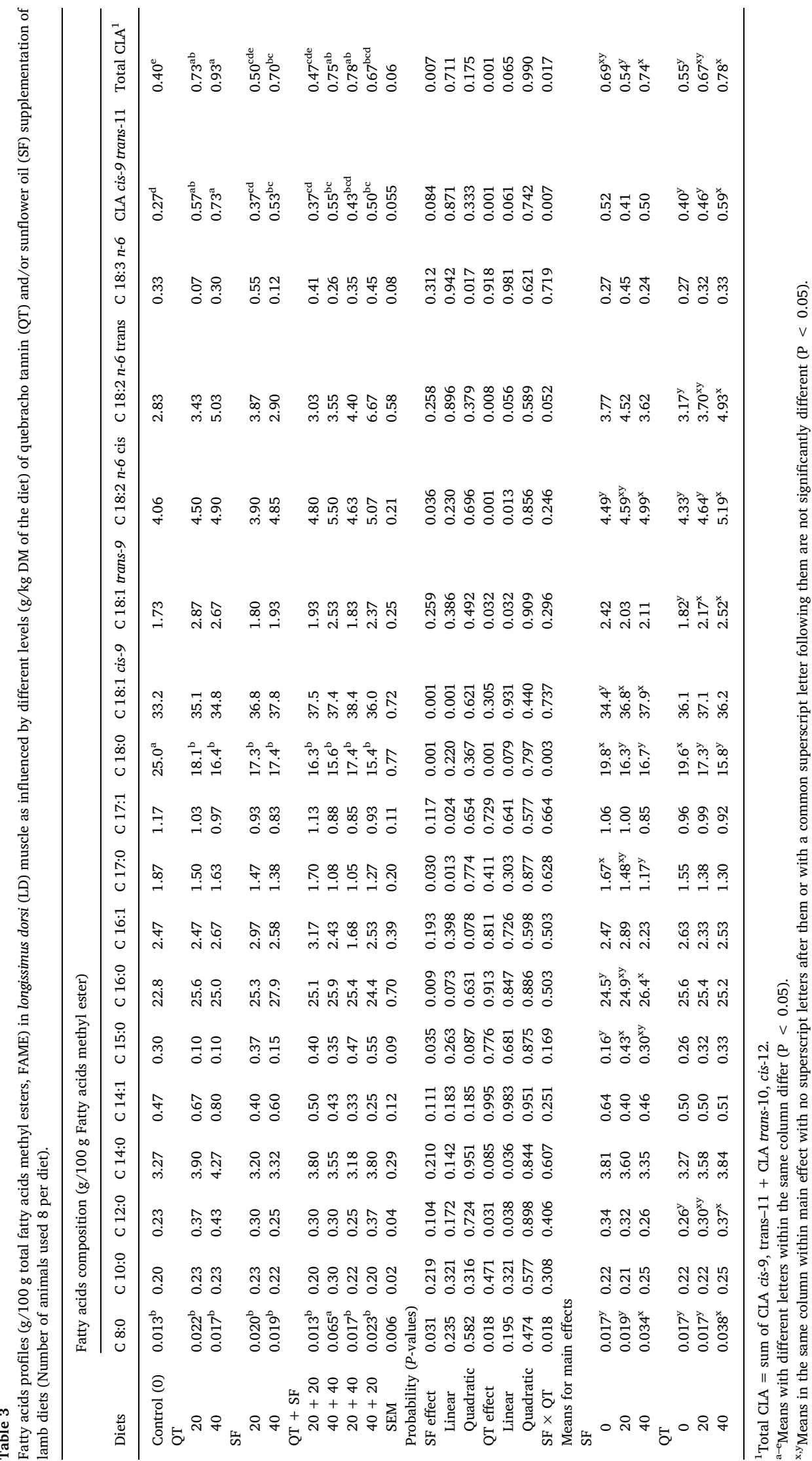


Table 4

Categories of fatty acids of intramuscular fat in longissimus dorsi muscle ( $\mathrm{g} / 100 \mathrm{~g}$ total fatty acid methyl esters) as influenced by different levels ( $\mathrm{g} / \mathrm{kg}$ DM of the diet) of quebracho tannin (QT) and/or sunflower oil (SF) supplementation of lamb diets (Number of animals used 8 per diet).

\begin{tabular}{|c|c|c|c|c|c|c|}
\hline \multirow[b]{2}{*}{ Diets } & \multicolumn{6}{|c|}{ categories of fatty acids } \\
\hline & $\begin{array}{l}\Sigma \mathrm{SFA}^{\mathrm{A}}(\mathrm{g} / 100 \mathrm{~g} \\
\text { FAME })\end{array}$ & $\begin{array}{l}\Sigma U_{S F A}{ }^{B}(g / 100 g \\
\text { FAME) }\end{array}$ & USFA/SFA & $\begin{array}{l}\text { ¿MUSFA }^{\mathrm{C}}(\mathrm{g} / 100 \mathrm{~g} \\
\text { FAME })\end{array}$ & $\begin{array}{l}\Sigma \text { PUSFA }^{\mathrm{D}}(\mathrm{g} / 100 \mathrm{~g} \\
\text { FAME })\end{array}$ & $\begin{array}{l}\text { MCFA }^{\mathrm{E}}(\mathrm{g} / 100 \mathrm{~g} \\
\text { FAME) }\end{array}$ \\
\hline Control (0) & 53.6 & 46.4 & 0.88 & 39.0 & 7.40 & $26.4^{\mathrm{c}}$ \\
\hline \multicolumn{7}{|l|}{ QT } \\
\hline 20 & 49.7 & 50.3 & 1.01 & 42.1 & 8.30 & $29.8^{\mathrm{ab}}$ \\
\hline 40 & 48.0 & 52.0 & 1.09 & 41.9 & 10.1 & $29.7^{\mathrm{ab}}$ \\
\hline \multicolumn{7}{|l|}{$\mathrm{SF}$} \\
\hline 20 & 48.2 & 51.8 & 1.08 & 43.0 & 8.83 & $28.8^{\mathrm{b}}$ \\
\hline 40 & 50.5 & 49.5 & 0.98 & 43.2 & 6.23 & $31.4^{\mathrm{a}}$ \\
\hline \multicolumn{7}{|l|}{$\mathrm{QT}+\mathrm{SF}$} \\
\hline $20+20$ & 47.8 & 52.2 & 1.09 & 44.3 & 7.93 & $29.2^{\mathrm{ab}}$ \\
\hline $40+40$ & 46.8 & 53.2 & 1.14 & 43.6 & 9.57 & $29.7^{\mathrm{ab}}$ \\
\hline $20+40$ & 47.9 & 52.1 & 1.09 & 42.9 & 9.17 & $28.8^{\mathrm{b}}$ \\
\hline $40+20$ & 45.9 & 54.1 & 1.18 & 42.0 & 12.1 & $28.6^{\mathrm{b}}$ \\
\hline SEM & 0.88 & 0.88 & 0.04 & 1.00 & 0.65 & 0.68 \\
\hline \multicolumn{7}{|c|}{ Probability ( $P$-values) } \\
\hline SF effect & 0.004 & 0.004 & 0.004 & 0.025 & 0.149 & 0.049 \\
\hline Linear & 0.307 & 0.307 & 0.330 & 0.064 & 0.856 & 0.244 \\
\hline Quadratic & 0.210 & 0.210 & 0.201 & 0.394 & 0.367 & 0.676 \\
\hline QT effect & 0.001 & 0.001 & 0.001 & 0.294 & 0.001 & 0.669 \\
\hline Linear & 0.025 & 0.025 & 0.020 & 0.571 & 0.010 & 0.697 \\
\hline Quadratic & 0.838 & 0.838 & 0.944 & 0.394 & 0.664 & 0.873 \\
\hline $\mathrm{SF} \times \mathrm{QT}$ & 0.432 & 0.432 & 0.432 & 0.264 & 0.137 & 0.003 \\
\hline \multicolumn{7}{|c|}{ Means for main effects } \\
\hline \multicolumn{7}{|l|}{$\mathrm{SF}$} \\
\hline 0 & $50.4^{x}$ & $49.6^{y}$ & $0.99^{y}$ & $41.0^{y}$ & 8.60 & 28.6 \\
\hline 20 & $47.3^{y}$ & $52.7^{x}$ & $1.12^{\mathrm{x}}$ & $43.1^{x y}$ & 9.63 & 28.9 \\
\hline 40 & $48.4^{\mathrm{y}}$ & $51.6^{x}$ & $1.07^{\mathrm{x}}$ & $43.3^{x}$ & 8.36 & 30.0 \\
\hline \multicolumn{7}{|l|}{ QT } \\
\hline 0 & $50.8^{\mathrm{x}}$ & $49.2^{\mathrm{y}}$ & $0.98^{y}$ & 41.9 & $7.41^{\mathrm{y}}$ & 29.1 \\
\hline 20 & $48.4^{\mathrm{y}}$ & $51.6^{\mathrm{y}}$ & $1.07^{\mathrm{x}}$ & 43.1 & $8.54^{y}$ & 29.2 \\
\hline 40 & $46.9^{y}$ & $53.1^{\mathrm{x}}$ & $1.14^{\mathrm{x}}$ & 42.6 & $10.5^{\mathrm{x}}$ & 29.4 \\
\hline
\end{tabular}

${ }^{\mathrm{a}-\mathrm{c}}$ Means with different letters within a column differ $(P<0.05)$.

${ }^{\mathrm{x}, \mathrm{y}}$ Means in the same column within main effect with no superscript letters after them or with a common superscript letter following them are not significantly different $(P<0.05)$.

${ }^{A} \Sigma S F A=$ Sum of the saturated fatty acids (C8, C10, C12, C14, C15, C16, C17, C18).

${ }^{\text {B }} \Sigma$ USFA $=$ Sum of the unsaturated fatty acids (C14:1, C16:1, C17:1, C18:1 cis-9, C18:1 trans-9, C 18:2 n-6 cis, C 18:2n-6 trans, C 18:3 n-6, Total CLA).

${ }^{\mathrm{C}} \Sigma$ MUSFA $=$ Sum of mono-unsaturated fatty acids (C14:1, C16:1, C17:1, C18:1 cis-9, C18:1 trans-9).

${ }^{D} \Sigma$ PUSFA $=$ poly-unsaturated fatty acids (C 18:2 n-6 cis, C 18:2n-6 trans, C 18:3 n-6, Total CLA).

${ }^{\mathrm{E}} \mathrm{MCFA}=$ medium chain fatty acids $=\operatorname{sum}(\mathrm{C}: 12+\mathrm{C}: 14+\mathrm{C}: 16)$.

C12 + C14 + C16) increased $(P=0.049)$ with SF addition to the diet, however, QT addition had no effect $(P=0.669)($ Table 4$)$.

The lipids in meat comprise both phospholipids of the membranes of the cells and organelles, and triacylglycerols (TAG) as reserves lipids stored in adipocytes or in the cytoplasm of muscular cells. Jerónimo et al. (2010) found the phospholipids are very rich on PUFA, however, TAG are rich in SFA and MUFA. The content of phospholipids is constant but that of the TAG is variable with the dietary level of energy. In other words, total FA content for the intramuscular fat should be considered; because lean meats often have more PUFA than fatter meat irrespective of the diet. When diet results in more meat PUFA, the reason could be a change in the rumen biohydrogenation, and it could also be due to the effect of energy density of the diets and performance of the animals (Rui Bessa, personal communication). In the current study, the tested diets were formulated to be isoenergetic. The diet effect on fat content of LD was not significant $(\mathrm{P}>0.05)$ (i.e. $\mathrm{SF} \times \mathrm{QT}$ effect), therefore, the change in the PUFA concentration in the current work could be attributed to an effect on rumen bio-hydrogentaion of unsaturated FA.

Reduction of stearic acid content in the experimental diets due to SF supplementation were 10.9 and 8.14 and $6.83 \mathrm{~g} / 100 \mathrm{~g}$ of total FA methyl esters for control, 20 and $40 \mathrm{~g} \mathrm{SF}$ per $\mathrm{kg}$ of the diet, respectively, which is assumed to be a dilution effect of oil supplementation. Therefore, the reduction of C18:0 in the LD could reflect the proportion of C18:0 in the diets. In association with that, the incomplete biohydrogenation of fatty acids (C18:1 trans9, C18:2 n-6cis, C18:2 n-trans6, CLA cis 9 trans 11 and total CLA) led to the increased proportion of these acids and decreased proportion of C18:0 in the fatty acids of LD. In contrast, diets supplemented with SF at the level of 55 and $110 \mathrm{~g} / \mathrm{kg}$ DM had no effect on the stearic acid content of intramuscular lipids of LD from animals with initial body weight of $426 \mathrm{~kg}$ (Noci et al., 2005). Peng et al. (2010) reported that adding different oilseeds to the diets did not change the stearic acid content of LD from ewes with initial body weight of approximate $40 \mathrm{~kg}$.

In a recent in vitro investigation (Vasta et al., 2009a) stated that addition of tannins lowered ruminal biohydrogenation by inhibiting the proliferation of ruminal microorganisms rather than by a direct interaction of tannins with the enzymes operating in 
the biohydrogenation pathway. Sackmann et al. (2003) reported that the biohydrogenation occurs largely with increasing aNDFom level in the diet. Moreover, Kepler and Tove (1967) concluded that the microorganisms responsible for the biohydrogenation are cellulolytic like Butyrivibrio fibrisolvens that proliferates largely in animals fed forage diet. Biohydrogenation in the rumen involves of two steps; the first step is converting the rumenic acid to vaccenic acid and the second step for a final biohydrogenation step forming stearic acid from vaccenic acid (Harfoot and Hazlewood, 1997). Vasta et al. (2009a) reported that tannins influenced the in vitro conversion of vaccenic acid to stearic acid to a greater extent than the previous step of the biohydrogenation. The reduction of stearic acid content in meat due to QT supplementation could be a result of the inhibition of microorganisms involved in the biohydrogenation of vaccenic acid, which is supported by the negative effect of QT on the digestion of aNDFom. This result is in agreement with Vasta et al. (2009a) who reported that the ratio for stearic acid/vaccenic acid was less for lambs fed a concentrate diet with tannin compared to lambs fed a tannin-free concentrate diet. Vasta et al. (2009b) observed a reduction in the concentration of the isobranched chain fatty acids in the rumen due to tannins addition. Iso-branched chain fatty acids are formed in the rumen by cellulolytic bacteria (Vlaeminck et al., 2006). In the current study, the QT-fed diets might have lowered the activities of cellulolytic microorganisms, which led to less stearic acid content in meat in line with the reduction of fiber digestibility. Moreover, the stearic acid content of LD muscle was not altered when the QT increased from 20 to $40 \mathrm{~g} / \mathrm{kg}$ of DM. This is in concordance to results of aNDFom digestion, which showed no significant reduction, observed when QT increased from 20 to $40 \mathrm{~g} / \mathrm{kg}$ of DM.

The inclusion of QT in the diet increased CLA C18:2 c9t11 in meat above that achieved with SF $(P=0.007)$. This result supports the hypothesis of Priolo et al. (2005) proposing an interaction between dietary condensed tannins and ruminal biohydrogenation. In a recent study by Francisco et al. (2015), the inclusion of increasing levels of condensed tannins (2.7, 7.0 and $15.0 \mathrm{~g} / \mathrm{kg} \mathrm{DM}) \mathrm{extracted}$ from Cistus ladanifer on diets containing different levels of vegetable oil (0, 40 and $80 \mathrm{~g} / \mathrm{kg} \mathrm{DM}$ ) had no effect on CLA content of intramuscular fat. However, the levels of condensed tannins addition to the diet in the study of Francisco et al. (2015) were lower compared to those used in the current study (up to $40 \mathrm{~g} / \mathrm{kg}$ of DM). Furthermore, the low level of QT supplementation (i.e., $20 \mathrm{~g} / \mathrm{kg}$ DM) did not influence the CLA content of meat. This finding illustrates that level of condensed tannins should be taken into consideration when condensed tannins are added to the diet supplemented with vegetable oil to enhance CLA C18:2 c9t11 in meat.

\section{Conclusion}

The inclusion of QT in the diet increased CLA C18:2 c9t11 content in meat above that achieved with SF supplementation. Diet supplemented with $20 \mathrm{SF}$ and $40 \mathrm{QT}$ (g/kg diet) increased the content of conjugated linoleic acid (C18:2 c9t11) in the intramuscular fat of lambs. Furthermore, the interaction of QT and SF synergistically combines the effects of SF (which engender a large amount of unsaturated fatty acids) with that of QT (which reduce the efficiency of ruminal microroganims and bio-hydrogenation of saturated fatty acids in the diet, thereby increasing the proportion of partially unsaturated fatty acids.

\section{Conflict of interest}

None.

\section{Acknowledgment}

We acknowledge the financial support through the grant (No. ARP-28-61) from King Abdulaziz City for Science and TechnologySaudi Arabia.

\section{References}

Al-Dobaib, S.N., 2009. Effect of different levels of Quebracho tannin on nitrogen utilization and growth performance of Najdi sheep fed alfalfa (Medicago sativa) hay as a sole diet. Anim. Sci. J. 80, 532-541.

Al-Dobaib, S.N., Kamel, H.E.M., 2012. Effect of sunflower oil supplementation on nutrients digestibility and CLA content of dromedary milk. J. Camel Pract. Res. 19, 254-276.

Ammar, H., López, S., Salem, A.Z.M., Bodas, R., González, J.S., 2011. Effect of saliva fromsheep that have ingested quebracho tannins on the in vitro rumenfermentation activity to digest tannin-containing shrubs. Anim. Feed Sci. Technol. 163, 77-83.

Association of official analytical chemist, 1995. Official Methods of Analyses, 15th ed., Washington, DC.

Barry, T.N., Manley, T.R., 1984. The role of condensed tannins in the nutritional value of Lotus pedunculatus for sheep. 2. Quantitative digestion of carbohydrates and proteins. Brit. J. Nutr. 51, 493-504.

Bessa, R.J.B., Portugal, P.V., Mendes, I.A., Santos-silva, J., 2005. Effect of lipid supplementationon growth performance, carcass and meat quality and fatty acid composition ofintramuscular lipids of lambs fed dehydrated Lucerne or concentrate. Lives. Prod. Sci. 96, 185-194.

Butter, N.L., Dawson, J.M., Buttery, P.J., 1999. Effects of dietary tannins on ruminants. In: Caygill, J.C., Mueller-Harvey, I. (Eds.), Secondary Plant Products: Antinutritional and Beneficial Actions in Animal Feeding. Nottingham Univ. Press, United Kingdom, pp. 51-70.

Carulla, J.E., Kreuzer, M., Machmuller, A., Hess, H.D., 2005. Supplementation of Acacia mearnsii tannins decreases methanogenesis and urinary nitrogen in forage-fed sheep. Aust. J. Agric. Res. 56, 961-970.

Cieslak, A., Zmora, P., Pers-Kamczyc, E., Sadowinska, A., Salem, A.Z.M., Kowalczyk, D., Stochmal, A., Zbonik, P., Szumacher-Strabel, M., 2014. Effects of two sources oftannins (Quercus L. and Vaccinium vitis idaea L.) on rumenmicrobial fermentation: an in vitro study. Ital. J. Anim. Sci 13 (2), $290-294$.

Cruz-Hernandez, C., Kramer, J.K.G., Kennelly, J.J., Glimm, D.R., Sorensen, B.M., Okine, E.K., Goonewardene, L.A., Weselake, R.J., 2007. Evaluating the conjugated linoleic acid and trans 18:1 isomers in milk fat of dairy cows fed increasing amounts of sunflower oil and a constant level of fish oil. J. Dairy Sci. 90, 3786-3801.

Díaz, M.T., Alvarez, I., De la Fuente, J., Sanudo, C., Campo, M.M., Oliver, M.A., Font, I., Furnols, M., Montossi, F., San Julián, R., Nute, G.R., Cañeque, V., 2005. Fatty acid composition of meat from typical lamb production systems of Spain, United Kingdom, Germany and Uruguay. Meat Sci. 71, $256-263$.

Folch, J., Lees, M., Stanley, G.H.S., 1957. Simple method for the isolation and purification of total lipids from animal tissues. J. Biol. Chem. 226, 497-509.

Francisco, A., Dentinho, M.T., Alves, S.P., Portugal, P.V., Fernandes, F., Sengo, S., Jerónimo, E., Oliveria, M.A., Costa, P., Sequeira, A., Bessa, R.J.B., Santos-Silva, J., 
2015. Growth performance, carcass and meat quality of lambs supplemented with increasing levels of a tanniferous bush (Citus ladanifer L.) and vegetable oils. Meat Sci. 100, 275-282.

Harfoot, G.C., Hazlewood, G.P., 1997. Lipid metabolism in the rumen. In: Hobson, P.N., Stewart, C.S. (Eds.), The Rumen Microbial Ecosystem. Blackie Academic and Professional, London.

Hernandez, P., Salem, A.Z.M., López, S., Sun, X.Z., Rojo, R., Camacho, L.M., Elghandour, M.M.Y., Ronquillo, M.G., 2014. Influence of Salixbabylonica and Leucaena leucocephala leaf extracts on ruminalfermentation characteristics, urinary purine derivativeexcretion and microbial protein synthesis of lambs. Livest. Sci. 163 , $80-84$.

Jerónimo, E., Alves, S.P., Dentinho, M.T.P., Martins, S.V., Prates, J.A.M., Vasta, V., Santos-silva, J., Bessa, R.J.B., 2010. The effect of grape seed extract and Cistus ladanifer $L$. and vegetable oil supplementation on fatty acid composition of abomasal digesa and intra- muscular fat of lambs. J. Agric. Food Chem. 58, $10710-10721$

Kepler, C.R., Tove, S.B., 1967. Biohydrogenation of unsaturated fatty acids III. Purification and properties of a linoleate $\Delta^{12}-$ cis, $\Delta^{11}$-trans- isomerase from butyrivibrio fibrisolvens. J. Biol. Chem. 242, 5686-5692.

Komolong, M.K., Barber, D.G., McNeill, D.M., 2001. Post-ruminal protein supply and N retention of weaner sheep fed on a basal diet of lucerne hay (Medicago sativa) with increasing levels of quebracho tannins. Anim. Feed Sci. Technol. 92, 59-72.

Kramer, J.K., Fellner, V., Dugan, M.E., 1997. Evaluating acid and base catalyst in the methylation of milk and rumen fatty acids with special emphasis on conjugated dienes and total trans fatty acids. Lipids 32, 1219-1228.

Noci, F., Monahan, F.J., French, P., Moloney, A.P., 2005. The fatty acid composition of muscle fat and subcutaneous adipose tissue of pasture-fed beef heifers: influence of the duration of grazing. J. Anim. Sci. 83, 1167-1178.

Peng, Y.S., Brown, M.A., Wu, J.P., Liu, Z., 2010. Differ oilseed supplements alter fatty acids composition of different adipose tissues of ewes. Meat Sci. 85, 452-459.

Piperova, L.S., Sampugna, J., Teter, B.B., Kalscheur, K.F., Yurawecz, M.P., Ku, Y., Ku, Y., Morehouse, K.M., Erdman, R.A., 2002. Duodenal and milk transoctadecenoic and conjugated linoleic acid (CLA) isomers indicate that postabsorptive synthesis is the predominant source of cis-9-containing CLA in lactating dairy cows. J. Nutr. 132, 1235-1241.

Priolo, A., Waghorn, G.C., Lanza, M., Biondi, L., Pennisi, P., 2000. Polyethylene glycol as a means for reducing the impact of condensed tannins in carob pulp: effects on lamb growth performance and meat quality. J. Anim. Sci. 78, 810-816.

Priolo, A., Bella, M., Lanza, M., Galofaro, V., Biondi, L., Barbagallo, D., Ben Salem, H., Pennisi, P., 2005. Carcass and meat quality of lambs fed fresh sulla (Hedysarum coronarium L.) with or without polyethylene glycol or concentrate. Small Rumin. Res. 59, 281-288.

SAS Institute Inc, 2001. SAS/STAT User's Guide. Version 8.0 Edition. SAS Institute INC, Cary, North Carolina, USA.

Sackmann, J.R., Duckett, S.K., Gills, M.H., 2003. Effects of forage and sunflower oil levels on ruminal biohydrogenation of fatty acids and conjugated linoleic acid formation in beef steers fed finishing diets. J. Anim. Sci. 81, 3174-3181.

Salem, A.Z.M., López, S., Ranilla, M.J., González, J.S., 2013. Short to medium-term effects of consumption of quebracho tannins on totaland parotid saliva production and composition in sheep and goats. J. Anim. Sci. 91 (3), 1341-1349.

Salem, A.Z.M., Kholif, A.E., Olivares, M., Elghandour, M.M.Y., Mellado, M., Arece, J., 2014. Influence of S. babylonica extract on feed intake, growth performance and diet in vitro gas production profile in younglambs. Trop. Anim. Health Prod. 46 (1), 213-219.

Van Soest, P.J., Robertson, J.B., Lewis, B.A., 1991. Method for dietary fiber, neutral detergent fiber and non-starch polysaccharides in relation to animal nutrition. J. Dairy Sci. 74, 3583-3597.

Vargas-Bello-Pérez, E., Larraín, R.E., 2017. Impact of fat from ruminants' meat on cardiovascular health and possible strategies to alter lipid composition. J. Sci. Food Agric. 97, 1969-1978.

Vasta, V., Mele, M., Serra, A., Scerra, M., Luciano, G., Lanza, M., Priolo, A., 2009a. Metabolic fate of acids involved inruminal biohydrogenation in sheep fed concentrate or herbage with or without tannins. J. Anim. Sci. 87, 2674-2684.

Vasta, V., Priolo, A., Scerra, M., Hallett, K.G., Wood, J.D., Doran, O., 2009b. Desaturase protein expression and fatty acid composition of longissimus dorsi muscle in lambs fed green herbage or concentrate with or without added tannins. Meat Sci. 82, 357-364.

Vlaeminck, B., Fievez, V., Cabrita, A.R.J., 2006. Factors affecting odd- and branched-chain fatty acids in milk: a review. Anim. Feed Sci. Technol. 131, 389-417. 